\title{
Anterior ischemic optic neuropathy: a comparison of the optic disc area of patients with the arteritic and non- arteritic forms of the disease and that of normal controls
}

\author{
Neuropatia óptica isquêmica anterior:estudocomparativoda área dodiscoópticode \\ pacientes com as formas arterítica e não-arterítica da doença e de controles normais
}

Mário Luiz Ribeiro Monteiro ${ }^{1}$

\begin{tabular}{|l|}
\hline ABSTRACT \\
\hline Purpose: To evaluate the optic disc area of patients with non-arteritic \\
anterior ischemic optic neuropathy (NA-AION) and arteritic anterior \\
ischemic optic neuropathy (A-AION) and compare the results between \\
each other and with those from controls in order to verify the existence \\
and the magnitude of anatomical factors predisposing to the development \\
of anterior ischemic optic neuropathy. Methods: This is a case-controlled \\
study of the optic disc area of 24 consecutive patients affected with NA- \\
AION, 13 patients with A-AION and 24 consecutive healthy normals, \\
sex- and age-matched with the patients with the NA-AION group. \\
Measurements of optic disc area were performed for each studied group \\
using disc photographs projected, measured and corrected for the \\
refractive error and the keratometric readings, according to Littmann's \\
method in each studied group. The results were compared using variance \\
analysis. Results: The mean areas and standard deviations of the optic \\
discs frompatients with NA-AION, A-AION and normals were respectively \\
$1.99 \pm 0.35$ mm ${ }^{2}, 2.29 \pm 0.39$ mm ${ }^{2}$ and $2.49 \pm 0.53$ mm ${ }^{2}$. The statistical \\
analysis revealed that the mean areas of the optic disc of patients with \\
NA-AION were significantly different from those of normal controls. No \\
statistical difference was found between A-AION and normal controls. \\
Conclusions: NA-AION occurs predominantly in small discs while the \\
arteritic form of the disease shows no such preference. Factors related \\
to optic disc structure play a role in the pathophysiology of NA-AION. \\
The occurrence of AION in large optic optic discs should raise the \\
suspicion of temporal arteritis. On the other hand, small optic disc areas \\
do not rule out that vasculitis.
\end{tabular}

Keywords: Optic neuropathy, ischemic; Optic disk; Optic nerve diseases; Temporal arteritis

\section{INTRODUCTION}

Anterior ischemic optic neuropathy (AION) is one of the most frequent diseases affecting the optic nerve and may lead to severe visual loss in the elderly. Classified as arteritic (A-AION) and non-arteritic (NA-AION), AION is characterized by sudden visual loss, altitudinal visual field loss, afferent pupillary defect and optic disc edema in the acute phase ${ }^{(1)}$. A-AION may be caused by several vasculites especially giant cell arteritis while NA-AION is not related to such conditions ${ }^{(1)}$. While A-AION is thought to be caused by arteritic occlusion of the posterior short ciliary arteries, the pathogenesis of 
806 Anterior ischemic optic neuropathy: a comparison of the optic disc area of patients with the arteritic and non-arteritic forms of the disease and that of normal controls

NA-AION is not completely understood. Although occlusion of the ciliary arteries by thrombi or emboli is a possible explanation, temporary hypoperfusion of the anterior portions of the optic nerve and choroid is the most likely pathogenetic mechanism $^{(1-2)}$.

Approximately $40 \%$ of patients with NA-AION show contralateral eye optic nerve involvement months or years after the first eye event ${ }^{(1)}$. Many such patients present systemic vasculopathies including arterial hypertension, diabetes mellitus and arteriosclerosis. Others however, present no such predisposing systemic factors even when displaying bilateral sequential involvement by NA-AION. Such occurrence suggests a predisposing anatomical factor in the pathogenesis of the condition.

The observation that a structural factor may render the optic disc more susceptible to vascular damage was first made in 1982 by Hoyt who pointed out that the optic discs of patients with NA-AION were usually small, with little or no physiologic cupping ${ }^{(3-6)}$. Subsequent studies confirmed this observation by studying the optic disc in the normal fellow eye in patients with unilateral AION. Several studies found small physiologic cups in eyes of patients with NA-AION ${ }^{(3-6)}$. These studies evaluated the optic disc in the normal fellow eye of patients with unilateral AION under the presumption that its appearance reflected the premorbid appearance of the affected disc. By observing small or absent physiologic cups in the contralateral normal eyes these studies assumed that the affected eyes had small discs, though direct measurements of the optic disc area were not performed.

More recently attention has been drawn to the evaluation of the real dimension of the optic disc, including size, perimeter, area, cupping and neuroretinal rim, particularly in glauco$\mathrm{ma}^{(7)}$. Such measurements can be obtained from disc photographs or optic disc analyzers. Measurements of disc photographs are precise, simple and inexpensive. Optic disc limits can be determined using enlargements of these photographs or images projected from slides ${ }^{(7-8)}$. The dimensions are subsequently corrected to compensate for optical factors of the eye and camera used in the study. Littmann's method may be used in this correction, taking into account the cornea curvature and the refractive error of the eye $\mathrm{e}^{(9)}$.

Some authors, evaluated the real dimensions of the optic disc and demonstrated that the disc area is significantly smaller in the fellow eyes of patients with NA-AION than in control eyes $^{(10-11)}$. Wiek however did not confirm this finding and suggested that there was no difference in disc area between patients with NA-AION and normal individuals ${ }^{(12)}$. The occurrence of small optic discs in eyes with NA-AION may have diagnostic implications in this condition. If discs with NAAION are in fact smaller than discs with A-AION, then a large optic disc in a patient with AION should raise the suspicion of temporal arteritis. The purpose of this study is therefore to evaluate the optic disc area of patients with NA-AION or A-AION and in normal controls in order to define whether optic disc areas tend to be smaller in NA-AION and to inves- tigate whether measuring the disc area actually helps diagnose giant cell arteritis and distinguish between the arteritic and non-arteritic forms of the disease.

\section{METHODS}

The study included 24 eyes (right eyes and left eyes) of 24 patients who had experienced sudden visual loss due to NAAION (Group 1); 13 eyes of 13 patients with A-AION (Group 2 ) and 24 eyes of 24 normal healthy individuals (Group 3) age and sex-matched with the patients of Group 1. AION was diagnosed based on clinical criteria $(1,2)$ and the study was performed after resolution of disc edema. All patients with giant cell arteritis had their diagnosis established by a biopsy. The inclusion criteria for patients and controls were: 1$) \mathrm{Ab}$ sence of media opacities that might prevent adequate disc photography; 2) Refractive error inferior to 6 spherical diopters and 3 cylindrical diopters in the eye to be studied; 3 ) Absence of glaucoma.

Patients and controls were submitted to a complete ophthalmic examination and disc photography with a TRC-FE Topcon retinal camera.

The control group consisted of 24 healthy individuals attending the clinic for refractive examination, paired by age and sex with the group of patients with NA-AION without any ocular disease. All of them had refractive error of less than 6 spherical diopters and 3 cylindrical diopters.

A fundus photograph of one eye from each of 24 patients with NA-ION was selected for study. In the 13 patients with A-AION only one eye was selected for study. In patients with both eyes affected by giant cell arteritis, an eye was chosen at random. Only one eye of each of the 24 normal controls was selected for study. The retinographic images were numbered and shuffled. The slides were subsequently introduced by another person into a Kodak carousel and projected onto the wall at a distance of $104 \mathrm{~cm}$ from the lens of the projector. The distance was adjusted by projecting a transparent sheet of graph paper so that a 10 -fold magnification would ensue. The contour line of each optic disc was drawn by the author, blinded to the name of the patient, and identified with the respective slide number. The slides were then projected a second time and a new set of drawings was produced. After determining the disc area with a planimeter, the measurements of each pair of drawings were averaged and divided by 100 in order to compensate for the magnification of the projection.

All calculated disc areas were corrected according to Littmann's method using the formula ${ }^{(9,13)}$ actual area $=$ measured area $\cdot(1.37)^{2} \cdot \mathrm{q}^{2}$

In this formula, which was developed through complex trigonometric calculations, "measured area" refers to the area obtained from the drawing of the optic disc (OD), the value 1.37 is a constant applied to 30-degree fundus photographs and " $\mathrm{q}$ " is a variable based on keratometric readings of the cornea curvature radius (mean curvature radius) and on the 
refractive error of the eye (spherical equivalent). The formula is therefore intended to correct factors related to the retinal camera and the photographed eye. Hyperopic values are positive while myopic values are negative. The value of "q" is obtained by applying the equation: $\mathrm{q}=0.01\left(\mathrm{a} \cdot \mathrm{A}^{2}-\mathrm{b} \cdot \mathrm{A}+\mathrm{c}\right)$. Littmann developed this formula through complex trigonometric calculations. The constants "a", "b" and "c" were determined by this author according to the radius of the cornea and have been published elsewhere ${ }^{(13)}$. "A" is the spherical equivalent.

The mean values and standard deviation of the optic disc area of each of the 3 groups were calculated and compared through variance analysis. p-values under 0.05 were considered significant.

\section{RESULTS}

\section{Descriptive analysis}

Eleven of the 24 patients with NA-AION (patients 1 to 24), were female. In 9 patients the optic nerve involvement was unilateral and in 15, bilateral. All patients in this group were white. Table 1 and Figure 1 summarize the findings in the 24 eyes chosen for the study (Group 1). The mean values and standard deviation (SD) for age, refractive error and OD area in this group were respectively $58.70 \pm 7.19$ years, $+1.22 \pm 1.58$ spherical diopters and $1.99 \pm 0.35 \mathrm{~mm}^{2}$. Minimum and maximum

\begin{tabular}{|c|c|c|c|c|c|c|}
\hline Patient & Sex & Age & Eye & Radius & SE & Área \\
\hline 1 & $\mathrm{~F}$ & 65 & LE & 7.56 & +2.00 & 2.30 \\
\hline 2 & $\mathrm{~F}$ & 56 & LE & 7.34 & +2.00 & 2.49 \\
\hline 3 & $\mathrm{~F}$ & 55 & RE & 7.38 & 0.00 & 2.36 \\
\hline 4 & M & 46 & $\mathrm{RE}$ & 7.71 & -0.25 & 1.56 \\
\hline 5 & M & 52 & LE & 7.39 & +0.25 & 2.11 \\
\hline 6 & $\mathrm{~F}$ & 47 & $\mathrm{RE}$ & 7.65 & +4.50 & 2.28 \\
\hline 7 & M & 59 & RE & 7.71 & +1.75 & 2.15 \\
\hline 8 & M & 61 & LE & 7.40 & +1.00 & 1.43 \\
\hline 9 & $\mathrm{~F}$ & 59 & RE & 7.60 & 0.00 & 1.62 \\
\hline 10 & $\mathrm{~F}$ & 67 & LE & 7.73 & +2.75 & 1.81 \\
\hline 11 & $\mathrm{~F}$ & 65 & LE & 7.30 & +1.37 & 1.83 \\
\hline 12 & M & 62 & LE & 7.64 & +1.50 & 2.00 \\
\hline 13 & $\mathrm{~F}$ & 60 & LE & 7.50 & +5.00 & 1.46 \\
\hline 14 & $\mathrm{~F}$ & 64 & $\mathrm{RE}$ & 7.28 & +1.00 & 1.91 \\
\hline 15 & M & 52 & RE & 7.38 & 0.00 & 2.53 \\
\hline 16 & $\mathrm{~F}$ & 66 & LE & 8.11 & +0.75 & 2.03 \\
\hline 17 & M & 68 & RE & 7.52 & +2.75 & 1.90 \\
\hline 18 & M & 50 & RE & 7.71 & +0.50 & 2.13 \\
\hline 19 & M & 64 & LE & 7.32 & 0.00 & 1.77 \\
\hline 20 & M & 65 & LE & 7.56 & +1.50 & 2.42 \\
\hline 21 & M & 62 & LE & 7.82 & +2.25 & 2.42 \\
\hline 22 & M & 42 & RE & 7.98 & -2.50 & 1.99 \\
\hline 23 & $\mathrm{~F}$ & 62 & RE & 7.07 & +1.25 & 1.29 \\
\hline 24 & M & 60 & RE & 7.39 & 0.00 & 2.10 \\
\hline
\end{tabular}

values for the OD areas in this group were, respectively 1.29 and $2.53 \mathrm{~mm}^{2}$.

Four of the 13 patients with A-AION (patients 25 to 37) were male. All were white. The optic nerve involvement was unilateral in 5 and bilateral in 8 patients. Age ranged from 64 and 86 years (mean \pm SD: $75.15 \pm 5.78$ years) and the spherical equivalent of the examined eyes ranged from -2.12 and +5.13 spherical diopters (mean $\pm \mathrm{SD}:+1.24 \pm 1.96$ ). The OD mean value was $2.29 \pm 0.39 \mathrm{~mm}^{2}$ (Table 2, Figure 1). The minimum and maximum values of the OD areas in this group were 1.51 and $2.94 \mathrm{~mm}^{2}$, respectively.

The control group consisted of 24 normal eyes from 24 normal subjects ( 11 females and 13 males) ranging from 45 to 70 years (mean $58.45 \pm 8.65$ years). The spherical equivalent ranged between -1.00 and +3.25 (mean $\pm \mathrm{SD}:+1.29 \pm 1.24$ ). Twenty subjects were white, two were yellow and 2 were brown in color. OD areas ranged from 1.76 and $3.58 \mathrm{~mm}^{2}$ (mean

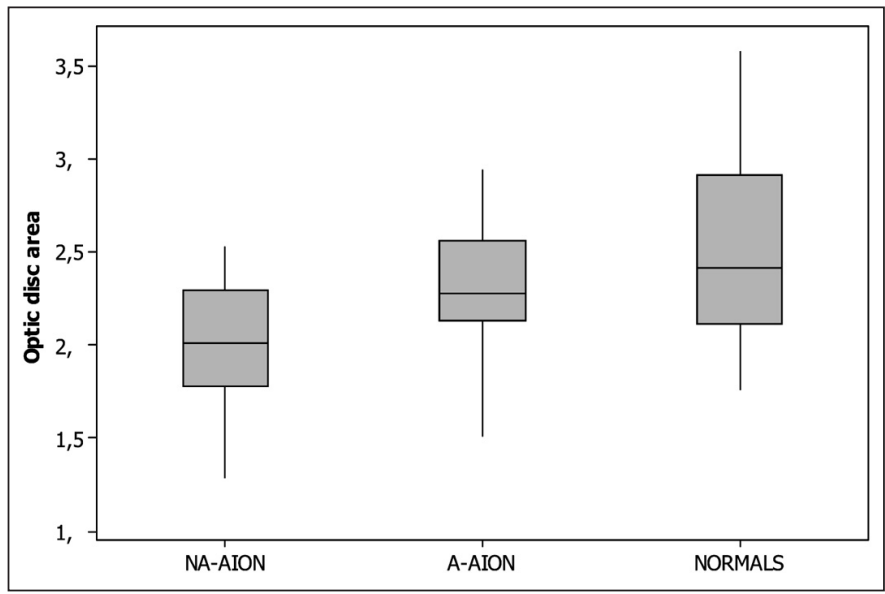

Figure 1 - Box plot chart showing the distribution of the optic disc area $\left(\mathrm{mm}^{2}\right)$ of patients with non-arteritic anterior ischemic optic neuropathy (NA-AION), arteritic anterior ischemic optic neuropathy (A-AION) and normal controls (NORMALS)

\begin{tabular}{|c|c|c|c|c|c|c|}
\hline Patient & Sex & Age & Eye & Radius & SE & Área \\
\hline 25 & $\mathrm{~F}$ & 75 & LE & 7.52 & 0.00 & 2.28 \\
\hline 26 & M & 76 & RE & 7.55 & +1.00 & 2.54 \\
\hline 27 & M & 86 & RE & 7.75 & +0.75 & 2.94 \\
\hline 28 & $M$ & 74 & RE & 7.38 & -2.12 & 2.72 \\
\hline 29 & $\mathrm{~F}$ & 70 & RE & 7.67 & +5.13 & 1.68 \\
\hline 30 & $\mathrm{~F}$ & 82 & LE & 7.27 & +4.00 & 1.51 \\
\hline 31 & M & 64 & RE & 7.96 & +0.50 & 2.44 \\
\hline 32 & $\mathrm{~F}$ & 75 & RE & 7.41 & -1.50 & 2.10 \\
\hline 33 & $\mathrm{~F}$ & 68 & RE & 7.05 & +2.00 & 2.30 \\
\hline 34 & $\mathrm{~F}$ & 75 & LE & 7.78 & +0.75 & 2.58 \\
\hline 35 & $\mathrm{~F}$ & 73 & RE & 7.89 & +2.50 & 2.25 \\
\hline 36 & $\mathrm{~F}$ & 83 & RE & 7.20 & +1.50 & 2.26 \\
\hline 37 & $\mathrm{~F}$ & 76 & $\mathrm{RE}$ & 7.40 & +1.62 & 2.17 \\
\hline
\end{tabular}


808 Anterior ischemic optic neuropathy: a comparison of the optic disc area of patients with the arteritic and non-arteritic forms of the disease and that of normal controls

$\left.2.49 \pm 0.53 \mathrm{~mm}^{2}\right)$. The minimum and maximum values for the OD areas in this group were 1.76 and $3.58 \mathrm{~mm}^{2}$, respectively. Table 3 and figure 1 summarize the findings in this group.

\section{Group comparisons}

The mean optic disc areas in each of the 3 groups were analyzed using the Kolmogorov-Smirnov and Bartlett tests and found to present a normal distribution with homogeneous variances. The values from the two groups were subsequently compared using variance analysis. The study showed a statistically significant difference $(\mathrm{p}=0.001)$ among the groups. Post hoc analysis revealed that Group 1 differed significantly from Group 3 (Tukey test, $p=0.001$ ). No significant difference was found between Group 2 and Group 3 (Tukey test, $\mathrm{p}=0.392$ ).

\section{DISCUSSION}

The mean values of the optic disc areas observed in this study (mean $=2.49 \mathrm{~mm}^{2}, \mathrm{SD}=0.53$ ) were within the range observed by other authors $\left(2.35-2.69 \mathrm{~mm}^{2}\right)^{(14-15)}$. Several earlier studies indicate that optic disc dimensions are not related to age, sex or refractive error, when high ametropias are exclu$\operatorname{ded}^{(7,14,16-17)}$. We therefore excluded eyes with high ametropias from all studied groups. Despite the absence of previous reports describing such relationships we made an effort to pair individuals from Group 1 and 3 with regard to sex and age. The

\begin{tabular}{|ccccccc|}
\hline \multicolumn{6}{|c}{$\begin{array}{l}\text { Table 3. Age and sex, radius of the corneas (mm), ametropias, and } \\
\text { optic disc areas }\left(\mathbf{m m}^{2}\right) \\
\text { Con }\end{array}$ from 24 normal control eyes (Group 3) } \\
Controls & Sex & Age & Eye & Radius & SE & Área \\
38 & $\mathrm{~F}$ & 65 & LE & 7.98 & +1.50 & 2.21 \\
39 & $\mathrm{~F}$ & 56 & $\mathrm{LE}$ & 7.50 & +1.75 & 1.76 \\
40 & $\mathrm{~F}$ & 50 & $\mathrm{RE}$ & 8.19 & 0.00 & 2.67 \\
41 & $\mathrm{M}$ & 45 & $\mathrm{RE}$ & 8.35 & +2.00 & 2.12 \\
42 & $\mathrm{M}$ & 47 & $\mathrm{LE}$ & 7.79 & -1.00 & 3.18 \\
43 & $\mathrm{~F}$ & 46 & $\mathrm{RE}$ & 7.89 & +0.63 & 3.04 \\
44 & $\mathrm{M}$ & 58 & $\mathrm{RE}$ & 7.87 & +3.00 & 2.62 \\
45 & $\mathrm{M}$ & 61 & $\mathrm{LE}$ & 7.42 & +1.63 & 2.36 \\
46 & $\mathrm{~F}$ & 54 & $\mathrm{RE}$ & 7.97 & -0.13 & 3.58 \\
47 & $\mathrm{~F}$ & 70 & $\mathrm{LE}$ & 7.62 & +2.75 & 1.78 \\
48 & $\mathrm{~F}$ & 62 & $\mathrm{LE}$ & 8.09 & +1.25 & 2.99 \\
49 & $\mathrm{M}$ & 61 & $\mathrm{LE}$ & 7.47 & 0.00 & 2.43 \\
50 & $\mathrm{~F}$ & 64 & $\mathrm{RE}$ & 7.69 & +2.00 & 2.41 \\
51 & $\mathrm{~F}$ & 64 & $\mathrm{RE}$ & 7.50 & +1.00 & 2.16 \\
52 & $\mathrm{M}$ & 47 & $\mathrm{RE}$ & 7.76 & +0.50 & 3.20 \\
53 & $\mathrm{~F}$ & 69 & $\mathrm{LE}$ & 7.59 & +3.25 & 1.89 \\
54 & $\mathrm{M}$ & 69 & $\mathrm{RE}$ & 7.68 & +1.63 & 1.87 \\
55 & $\mathrm{M}$ & 51 & $\mathrm{RE}$ & 7.47 & +0.50 & 2.31 \\
56 & $\mathrm{M}$ & 69 & $\mathrm{LE}$ & 7.85 & +2.00 & 2.70 \\
57 & $\mathrm{M}$ & 70 & $\mathrm{LE}$ & 7.76 & +3.25 & 2.11 \\
58 & $\mathrm{M}$ & 67 & $\mathrm{LE}$ & 7.64 & +0.75 & 2.50 \\
59 & $\mathrm{M}$ & 46 & $\mathrm{RE}$ & 7.85 & -1.00 & 3.45 \\
60 & $\mathrm{~F}$ & 57 & $\mathrm{LE}$ & 8.19 & +3.00 & 2.44 \\
61 & $\mathrm{M}$ & 55 & $\mathrm{RE}$ & 7.79 & +0.75 & 1.92 \\
\hline
\end{tabular}

mean refractive error was also similar for the two groups $(+1.22$ diopters for Group 1 and +1.29 diopters for Group 3).

Our results show a significant difference in OD size for patients with optic atrophy following NA-AION when compared with normal individuals and confirm the existence of predisposing structural anatomical factors in the development of NA-AION.

So far very few previous studies have evaluated the optic disc size in patients with AION. In 1988, Mansour et al., observed that patients with NA-AION had smaller optic discs than normal controls ${ }^{(10)}$. However, they studied only the normal eyes contralateral to eyes with visual loss in 9 patients with NAAION comparing them with 26 eyes from normal individuals. Measurements of the vertical and horizontal diameters of the disc were made directly from fundus photographs with the help of a magnifying loupe whereas the area of OD was estimated from the vertical and horizontal measurements ${ }^{(11)}$.

Using Littmann's method, Jonas et al., studied OD of 33 eyes affected with NA-AION and 25 normal contralateral eyes, and compared them with 457 normal eyes ${ }^{(11)}$. The obtained values $\left(2.37 \pm 0.29 \mathrm{~mm}^{2}\right.$ and $2.31 \pm 0.31 \mathrm{~mm}^{2}$, respectively, for the two groups) were significantly different from those observed for eyes of normal individuals $\left(2.69 \pm 0.70 \mathrm{~mm}^{2}\right)$. In another study, Jonas and $\mathrm{Xu}$ observed that optic discs were significantly smaller in eyes with AION than in eyes with glaucoma or eyes of normal individuals ${ }^{(18)}$. Some authors, however, did not find any difference between the OD areas of eyes affected with NA-AION (area $2.29 \pm 0.38 \mathrm{~mm}^{2}$ ) and eyes of normal individuals $\left(2.21 \pm 0.34 \mathrm{~mm}^{2}\right)^{(12)}$. These authors used a Rodenstock OD analyzer with video-digitized images in order to calculate the area of optic disc excavation. Klingbeil emphasizes that, due to problems related to the reflectivity of the scleral ring in the images, this method frequently produces OD contour lines different from those obtained clinically ${ }^{(19)}$. This limitation is particularly relevant in patients with small optic discs, the contour lines of which are often difficult to determine ("crowded disc"). Simpson et al., also point out that OD contour lines become imprecise due to video degradation $^{(15)}$. Thus, methodological differences and/or abnormalities in the studied populations may account for the discrepancy between our findings and those of other authors ${ }^{(12)}$ and other workers ${ }^{(10,14)}$

Our finding of small optic discs in patients with NA-AION seems to confirm the existence of structural factors predisposing towards the development of optic neuropathy. Some clinical characteristics do suggest the existence of such predisposing anatomical factors. For example, NA-AION may occur in a relatively young patient with no systemic disease and shortly afterwards affect the contralateral eye. Another interesting point is that relapse in the same eye is extremely rare. The disease is bilateral in up to $40 \%$ of cases but almost never recurs in a previously affected eye. It is conceivable that the retinal nerve fibers become crowded when passing through a small optic disc. This would imply greater mechanical resistance to the vascular supply of the optic disc and so contribute to the 
development of the disease ${ }^{(5)}$. An alternative explanation is that small discs would have fewer posterior ciliary arteries and that their watershed zones would be more prone to the development of NA-AION. Further anatomical studies correlating the number of posterior ciliary arteries to the size of the optic disc would be necessary to clarify some of these relationship.

Structural factors, however, are likely to contribute (as one of the factors) to the development of the disease since in many patients the disease is unilateral despite the presence of similar risk factors in the unaffected contralateral eye ${ }^{(20)}$. Furthermore, many of the eyes with NA-AION included in this study had relatively large OD areas (up to $2.64 \mathrm{~mm}^{2}$ ), that is, well within normal range.

These findings support the concept of NA-AION as a multifactorial disease ${ }^{(3-4,21)}$. Systemic diseases, such as high blood pressure, diabetes mellitus and arteriosclerosis may also act as predisposing factors by altering the optic nerve microcirculation. Such conditions could reduce the optic nerve blood supply or lead to a defective optic nerve head blood flow autoregulation. Triggering factors such as transient hypotension or vasospasm probably find in small optic discs, favorable conditions for the development of AION. Once the ischemic event has occurred, a blocked axoplasmic flow would cause the retinal nerve fibers to swell thereby aggravating optic disc crowding and further impairing the optic nerve head blood supply ${ }^{(6,21-22)}$.

Our study was designed to include the evaluation of the possible diagnostic importance of measuring OD areas in eyes affected with AION. Our findings show that, although a statistically significant difference in mean values between the groups could be observed, several patients affected with NAAION had OD areas similar to those of the normal control group, that is, well within normal range. If we consider the mean value of the control group $\left(2.49 \pm 0.53 \mathrm{~mm}^{2}\right)$ and consider 2 standard deviations of variation, normal values will range from 1.43 to $3.55 \mathrm{~mm}^{2}$ (mean $\pm 2 \mathrm{SD}$ ). Since eyes affected with NA-AION measured between 1.29 and $2.64 \mathrm{~mm}^{2}$, we have observed that very few of these eyes will fall outside the normal range. Therefore, while the size of the OD area may contribute to raise suspicions of NA-AION, isolated, its diagnostic value is quite limited.

As for the comparison between OD areas of eyes affected with A-AION and NA-AION our study demonstrated that the group of eyes with NA-AION had mean values (1.99 \pm $\left.0.35 \mathrm{~mm}^{2}\right)$ smaller than those from eyes with A-AION $(2.29 \pm$ $0.39 \mathrm{~mm}^{2}$ ) and that eyes with A-AION did not differed from normal eyes $(\mathrm{p}=0.392)$. This finding indicates that the suspicion of temporal arteritis should be reinforced in patients presenting both AION and large ODs. The study clearly shows, however, that A-AION will occasionally occur in eyes with small ODs and that the finding of AION in small discs does not rule out temporal arteritis. An analysis of the individual values of both groups of AION revealed a large degree of overlapping in OD area measurements. Patients with NAAION and A-AION had optic disc areas ranging from 1.51 to
$2.94 \mathrm{~mm}^{2}$, and from 1.29 to $2.64 \mathrm{~mm}^{2}$, respectively. Thus, in individual patients, isolated OD area measurements may not allow to distinguish arteritic from non-arteritic AION.

\section{CONCLUSIONS}

1. The mean optic disc areas of patients with NA-AION were significantly smaller than those of of normal individuals.

2. There was no statistical difference between the optic disc area of eyes with A-AION and normal controls.

3. NA-AION affected predominantly small discs, although it occasionally occurred in larger optic discs. There was much overlapping in optic disc area measurements when comparing normal eyes and eyes with NA-AION.

4. As a group, eyes with NA-AION have smaller optic disc areas than eyes affected by A-AION. When AION occurs in eyes with very large optic disc areas temporal arteritis should be suspected. On the other hand, small optic disc areas do not rule out the disease.

\section{RESUMO}

Objetivos: Calcular a área do disco óptico de pacientes com neuropatia óptica isquêmica anterior não arterítica (NOIANA) e com neuropatia óptica isquêmica anterior por arterite temporal (NOIA-A) comparando os resultados entre si e com o grupos controle para verificar a existência e a magnitude de fatores anatômicos predisponentes ao desenvolvimento da neuropatia óptica isquêmica anterior. Métodos: Estudo prospectivo, caso-controle das áreas dos discos ópticos de 24 pacientes acometidos por NOIA-NA, 13 com NOIA-A e 24 indivíduos controles normais. As medidas da área do disco óptico foram realizadas a partir de retinografias projetadas, sendo as medidas corrigidas levando em conta o erro refracional e a ceratometria de acordo com o método de Littmann em cada um dos grupos estudados. Os resultados foram comparados usando-se análise de variância. Resultados: Os valores médios e desvios-padrão para as áreas do disco óptico dos olhos com NOIA-NA, NOIA-A e normais foram respectivamente de $1,99 \pm 0,35 \mathrm{~mm}^{2} ; 2,29 \pm 0,39 \mathrm{~mm}^{2} \mathrm{e} 2,49 \pm 0,53 \mathrm{~mm}^{2}$. A análise estatística revelou diferença significativa entre o grupo de olhos de pacientes com NOIA-NA e os controles normais. Não houve diferença significativa entre os olhos com NOIA-A e os controles. Conclusões: A forma não arterítica da NOIA ocorre em olhos com discos ópticos pequenos, ao passo que a forma arterítica da doença não mostra esta preferência. Fatores anatômicos estruturais do disco óptico têm um papel importante na fisiopatogenia da NOIA-NA. A ocorrência de NOIA em disco óptico de grandes dimensões deve reforçar a suspeita de arterite temporal. Discos ópticos pequenos, por outro lado não permitem excluir aquela vasculite.

Descritores: Neuropatia óptica isquêmica; Disco óptico; Doenças do nervo óptico; Arterite temporal 
810 Anterior ischemic optic neuropathy: a comparison of the optic disc area of patients with the arteritic and non-arteritic forms of the disease and that of normal controls

\section{REFERENCES}

1. Kelman SE. Ischemic optic neuropathies. In: Miller NR, Newman NJ, editors. Walsh and Hoyt's Clinical Neuro-ophthalmology. Baltimore: Williams \& Wilkins; 1998. p.549-98.

2. Hayreh SS. Anterior ischaemic optic neuropathy. Differentiation of arteritic from non-arteritic type and its management. Eye. 1990;4(Pt 1):25-41.

3. Beck RW, Savino PJ, Repka MX, Schatz NJ, Sergott. Optic disc structure in anterior ischemic optic neuropathy. Ophthalmology. 1984;91(11):1334-7.

4. Doro S, Lessell S. Cup-disc ratio and ischemic optic neuropathy. Arch Ophthalmol. 1988;103(8):1143-4.

5. Feit RH, Tomsak RL, Ellenberger C. Structural factors in the pathogenesis of ischemic optic neuropathy. Am J Ophthalmol. 1984;98(1):105-8.

6. Beck RW, Servais GE, Hayreh SS. Anterior ischemic optic neuropathy. IX Cupto-disc ratio and its role in pathogenesis. Ophthalmology. 1987;94(11):1503-8.

7. Airaksinen PJ, Drance SM, Douglas GR, Schulzer M. Neuroretinal rim areas and visual field indices in glaucoma. Am J Ophthalmol. 1985;99(2):107-10.

8. Brigatti L, Bottoni F, Miglior S, Orzalesi N. Technical procedures and software for magnification-corrected morphometry of optic disk photography. Ophthalmologica. 1991;202(1):33-7.

9. Littmann H. Zur Bestimmung der wahren Grosse eines Objektes auf dem Hintergrund des lebenden Auges. Klin Monatsbl Augenheilkd. 1982;180:286-9.

10. Mansour AM, Shoch D, Logani S. Optic disk size in ischemic optic neuropathy. Am J Ophthalmol. 1988;106(5):587-9. Comment in: Am J Ophthalmol. 1989;107(6):685-6.

11. Jonas JB, Gusek GC, Naumann GO. Anterior ischemic optic neuropathy: nonarteritic form in small and giant cell arteritis in normal sized optic discs. Int Ophthalmol. 1988;12(2):119-25.

12. Wiek J, Funk J, Hansen LL. [Computer controlled analysis of the optic papilla in patients with anterior ischemic optic neuropathy]. Klin Monatsbl Augenheilkd. 1995;206(2):92-5. German.

13. Littmann H. Zur Bestimmung der wahren Grosse eines Objektes auf dem Hintergrund eines lebenden Auges. Klin Monatsbl Augenheilk. 1988;192:66-7.

14. Jonas JB, Gusek GC, Naumann GO. Optic disc, cup and neuroretinal rim size, configuration and correlations in normal eyes. Invest Ophthalmol Vis Sci. 1988;29(7):1151-8. Erratum in: Invest Ophthalmol Vis Sci. 1991;32(6):1893. Invest Ophthalmol Vis Sci. 1992;32(2):474-5.

15. Simpson AJ, Lee S, Hanna KJ, Bron AJ. A method for measuring neuroretinal rim area. Aust N Z J Ophthalmol. 1990;18(2):207-10.

16. Britton RJ, Stephen SM, Schulzer M, Douglas GR, Mawson DK. The area of the neuroretinal rim of the optic nerve in normal eyes. Am J Ophthalmol. 1987; 103(4):497-504.

17. Varma R, Tielsch JM, Quigley HA, Hilton SC, Katz J, Spaeth GL, Sommer A. Race-, age-, gender-, and refractive error-related differences in the normal optic disc. Arch Ophthalmol. 1994;112(8):1068-76.

18. Jonas JB, Xu L. Optic disc morpholophy in eyes after nonarteritic anterior ischemic optic neuropathy. Invest Ophthalmol Vis Sci. 1993;34(7):2260-5.

19. Klingbeil U. The Rodenstock optic nerve head analyser. In: Varma R, Spaeth GL, Parker KW, editor. The optic nerve in glaucoma. Philadelphia: J.B. Lippincott; 1993. p.222-54.

20. Monteiro MLR. Estudo comparativo da área do disco óptico, de pacientes acometidos por neuropatia óptica isquêmica anterior, atrofia óptica por outras causas e indivíduos normais. [tese]. Sao Paulo: Universidade de São Paulo; 1997.

21. Hayreh SS, Zimmerman B, Podhajsky P, Alward WLM. Nocturnal arterial hypotension and its role in optic nerve head and ocular ischemic disorders. Am J Ophthalmol. 1994;117(5):603-24.

22. Burde RM. Optic disk risk factors for nonarteritic anterior ischemic optic neuropathy. Am J Ophthalmol. 1993;116(6):759-64. Comment in: Am J Ophthalmol. 1994;117(6):822. 